\title{
炭化クロム被覆ダイヤモンド粒子の耐酸化性，耐熱性
}

\author{
島上誠司 ${ }^{*}$, 福田洋一*, 久田栄一*, 沖 猛雄 ${ }^{* *}$
}

\section{Oxidation and Thermal Resistance of Chromium-Carbide Coated Diamond Grains}

\author{
Seiji SHIMAKAMI*, Yoichi FUKUTA*, Eiichi HISADA* and Takeo OKI**
}

Key Words : Oxidation Resistance, Thermal Resistance, Disproportionation, Chromium-Carbide, Molten Salt Bath

\section{1. 緒言}

工業用ダイヤモンドの耐酸化性，耐熱性については金

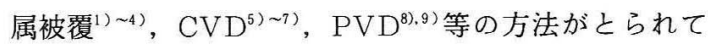
いるが, まだ問題点がある。ダイヤモンド粒子表面に析 出させたクロム炭化物層が, ダイヤモンドの耐酸化性, 耐熱性におよぼす役割を明らかにするために，本研究で は溶融塩レスプロポーショネーション反応による被覆ダ イヤモンド粒子の耐酸化性, 耐熱性について調べた。

\section{2. 方法}

実験の試料として用いた炭化クロム被覆ダイヤモンド 粒子は, 一般に溶融塩不均化反応法 ${ }^{10)}$ (13) と呼ばれる方 法により作製した。すなわち, $\mathrm{BaCl}_{2}-\mathrm{KCl}-\mathrm{NaF}$ 系を基 塩とし，これにクロム金属およびクロム酸化物を添加す ることにより, 溶融混合塩浴を調製し, この浴中に市販

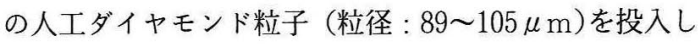
た後, 所定の条件（温度 : $900 \sim 950^{\circ} \mathrm{C}$, 時間： 3 時間） で浸せき反応させ，ダイャモンド粒子表面に炭化クロム 層を形成させた。得られた炭化クロム被覆ダイヤモンド 粒子を蒸留水で洗浄した後, これを各種実験に供した。 なお炭化クロム被覆ダイヤモンド粒子の特性評価のため の比較試料として, 未被覆ダイヤモンド粒子を用いた。

試料は $700^{\circ} \sim 800^{\circ} \mathrm{C}$ 温度条件下の電気炉内に挿入し, 大気中で30分間加熱処理した。処理後の試料は直ちに炉 から取り出し放冷した。加熱処理した試料表面の評価は 走查型電子顕微鏡（秼）日立製作所製S-450型，以下SEM と略す）観察によって行った。

\section{3. 結果および考察}

図 1-a）は加熱処理前の未被覆ダイヤモンド粒子の

*琍ノリタケカンパニーリミテド（テ451 愛知県名古屋市西 区則武新町3-1-36)

Noritake Co., Ltd. (1-36, Noritake-shinmachi 3-chome, Nishi-ku, Nagoya-shi, Aichi 451)

**名古屋大学工学部（宁464 愛知県名古屋市千種区不老町）

Fac. of Eng., Nagoya Univ. (Furo-cho, Chikusa-ku,

Nagoya-shi, Aichi 464)
SEM写真である。図 1-a）の上図から明らかなよう に, 粒子の形状は合成ダィヤモンド特有の八面体の \{111\} 面のあのに六面体の $\{100\}$ 面が現れた型となっ ている。また, 下図からは, 粒子の表面状態は非常に平 滑な状態であることが観察できる。また，表面上に樹枝 状の模様が認められるが，この模様は金属触媒法によっ て合成されるダイヤモンド特有のものであると考えられ る。図 2 は加熱処理前の炭化クロム被覆ダイヤモンド粒 子のX線回折図を示す。これから，表面には炭化クロム ( $\mathrm{Cr}_{7} \mathrm{C}_{3}$ 等) が存在することが分かる。そのSEM写真を 図 3-a）に示す。そのダイヤモンド粒子表面上に炭化 クロムが析出し, 被覆が形成され, 未被覆ダイヤモンド 粒子の表面とは異なる様相を呈していることが観察でき る。なお, 本試料の炭化クロム被覆量を測定した結果, 被覆ダイヤモンド重量に対して約17wt\%であった。被 覆の厚さは約 $1.4 \mu \mathrm{m}$ であった。

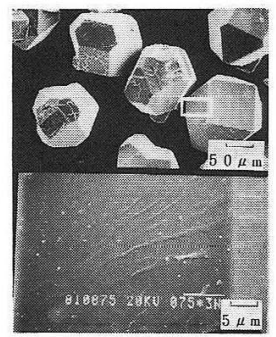

a )

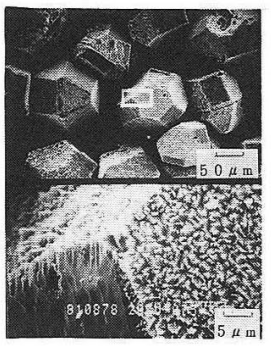

c )

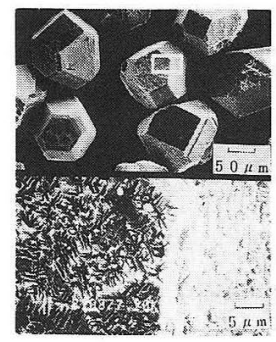

b )

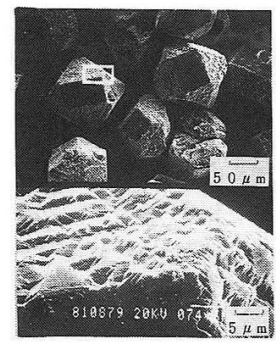

d )
Fig. 1 SEM photographs no coated diamond grains. Hoat treatment condition; a) no, b) at $700^{\circ} \mathrm{C}$ for $30 \mathrm{~min}, \mathrm{c}$ ) at $750^{\circ} \mathrm{C}$ for $30 \mathrm{~min}$ and d) at $800^{\circ} \mathrm{C}$ for $30 \mathrm{~min}$ 


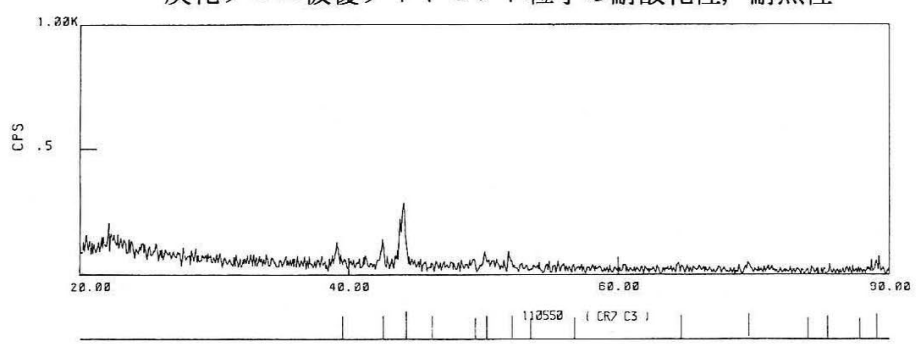

Fig. 2 XRD pattern of chromium carbide coated diamond grains.

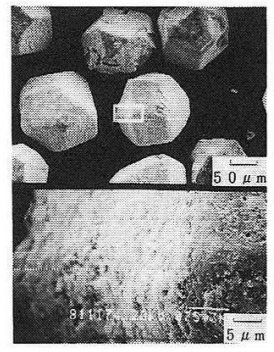

a)

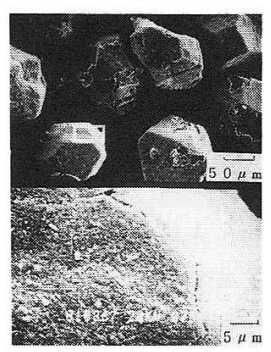

c)

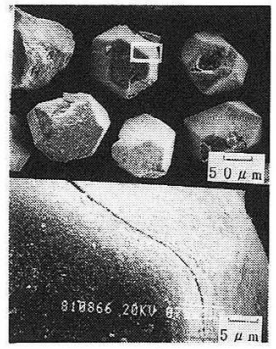

b )

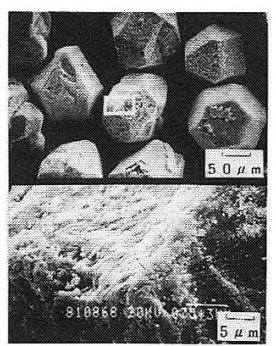

d )
Fig. 3 SEM photographs of $\mathrm{Cr}-\mathrm{C}$ coated diamond grains. Heat treatment condition; a) no, b) at $700^{\circ} \mathrm{C}$ for $30 \mathrm{~min}, \mathrm{c})$ at $750^{\circ} \mathrm{C}$ for $30 \mathrm{~min}$ and d) at $800^{\circ} \mathrm{C}$ for $30 \mathrm{~min}$

図 1 - b ）は $700^{\circ}$ Cで30分加熱処理した未被覆ダイヤ モンド粒子のSEM写真である。この図からダイヤモン ド粒子の形状変化はほとんど涩められないが，粒子表面 には微細なエッチピットが観察できる。ダイヤモンド粒 子は大気中において, すでに $700^{\circ} \mathrm{C} て ゙$ 酸化による劣化が 生じていることが分かる。一方, 図 3-b）は同条件で 処理した炭化クロム被覆ダイヤモンド粒子のSEM写真 である。被覆を行ったダイヤモンド粒子には, 形状, 表 面状態ともに変化は認められない。

図 1 -c）は750 Cで30分加熱処理した未被覆ダイヤ モンド粒子のSEM写真である。この図から, 粒子の形 状自体には大きな変化は無いが, 表面のエッチピットは 大きくなり, 粒子の陵の部分では, その変化は大きく陵 形状変化が観察される。また，その変化は $\{100\}$ 面よ り \{111\} の方が大きいことも観察され, $700^{\circ} \mathrm{C}$ 加熱処理 品より劣化が進行していることが認められた。図 3-c) は $750^{\circ} \mathrm{C}$ で30分加熱処理した炭化クロム被覆ダイヤモ ンド粒子のSEM写真である。 $750^{\circ} \mathrm{C} 30$ 分加熱処理では, $700^{\circ} \mathrm{C} 30$ 分加熱処理に比較して炭化クロム被覆表面が若 干劣化するが, 未被覆ダイヤモンドの場合のように粒子 の陵の部分に現れた顕著な变化は一切認められない。

図 1 -d）は800 Cで30分加熱处理した未被覆ダイヤ モンド粒子のSEM写真である。 $800^{\circ} \mathrm{C} の$ 処理では粒子 の形状の乱れが生じ, 表面の少化や陵形状变化の程度は かなり激しいことが分かる。一方，図 3-d）は同条件 で加熱処理した炭化クロム被覆ダイヤモンド粒子の SEM写真である。この図から, 粒子の表面状態はそれ 以下の温度での処理に比較して劣化が若干認められるが, 未被覆品で観察された粒子形の変形はごく小さく，陵形 状変化はほとんどないことが分かる。

これらの実験および観察により, 炭化クロム被覆層は 空気中加熱による酸化に対して内部ダイヤモンドを保護 していることが分かる。

\section{4. 結 論}

以上, 炭化クロム被覆ダイヤモンド粒子の空気中耐熱 性, 耐酸化性について, 未被覆ダイヤモンド粒子と比較 することにより検討したが, 今回の実験における最高温 度である $800^{\circ} \mathrm{C}$ での加熱処理で, 炭化クロム被覆ダイヤ モンド粒子は若干の劣化は示すむのの, 未被覆ダイヤモ ンド粒子に比較して, 熱酸化劣化が極めて小さく, 炭化 被覆層は内部に存在するダイヤモンドの耐酸化性, 耐熱 性を向上させることが分かった。

(1988-12-8 受理)

\section{文献}

1） ○.リンドストローム，他；特公昭49-13666（1974）

2) 石塚 博; 特公昭48-29716 (1973)

3) R. M. サッコ; 特公昭45-22477 (1970)

4) H. H. フェーグス; 特公昭52-31597 (1977)

5) A. G. ワイルダー, 他; 特公昭53-37599 (1978)

6 ) 吉川昌範, 他 ; 特開昭61-297079 (1986)

7 ) 戸倉 和, 吉川昌範; 精密工学会誌, 53，4 (1987)

8) R.J. キャベネー；特公昭52-14874 (1977)

9) 片岡和喜 ; 特公昭56-26548 (1981)

10）沖 猛雄, 谷川 純; 溶融塩, 25,115 (1982)

11）沖 猛雄，谷川 純 ; 金属表面技術，31，561（1980）

12）冲 猛雄; 金属表面技術協会第61回学術講演大会講演要旨 集, C21 (1980)

13) T. Oki and J. Tanikawa ; Proc. of the 1st Int. Symp. on Molten Salt Chem. and Tech. p. 265 (Electrochemical Soc. Japan, 1983) 